\title{
Chinese Crested
}

National Cancer Institute

\section{Source}

National Cancer Institute. Chinese Crested. NCI Thesaurus. Code C53947.

The Chinese Crested comes in two distinct varieties: one is hairless except for its feet, head and tail, and called the Hairless; the other is called the Powder Puff. The Powder Puff has a long coat. Both come in numerous colors; solid, mixed or spotted all over. Height: 12 inches (30 cm.) Weight: not over 10 pounds (4.5 kg.) 